\title{
CHILDREN WITH CHRONIC RENAL FAILURE ON CONSERVATIVE MANAGEMENT: CLINICAL PROFILE AND FAMILY CONFIGURATION
}

\section{CRIANÇAS COM DOENÇA RENAL CRÔNICA EM TRATAMENTO CONSERVADOR: PERFIL CLÍNICO E CONFIGURAÇÃO FAMILIAR}

\author{
Fernanda LISE ${ }^{1}$; Eda SCHWARTZ ${ }^{2}$; Viviane Marten MILBRATH ${ }^{3}$; Juliana DALL'AGNOL ${ }^{4}$ \\ 1. Mestre, Doutoranda no Programa de Pós-Graduação da Faculdade de Enfermagem da Universidade Federal de Pelotas - UFPel, \\ Pelotas, RS, Brazil. fernandalise@ gmail.com; 2. Professora, Doutora, Bolsista de Produtividade em Pesquisa CNPq, Programa de Pós- \\ Graduação da Faculdade de Enfermagem da Universidade Federal de Pelotas; 3. Professora, Doutora, Universidade Federal de Pelotas - \\ UFPel, Pelotas, RS, Brazil; 4. Acadêmica de Enfermagem, Faculdade de Enfermagem da Universidade Federal de Pelotas - UFPel, \\ Pelotas, RS, Brazil.
}

\begin{abstract}
This study aimed to know the clinical profile and the configuration of children on renal conservative management. It is a descriptive methodology of qualitative approach, developed from semi-structured interviews and the construction of the genogram and ecomap of family caregivers of children on renal conservative management. The data collection occurred from April to August 2015 and it was used descriptive analysis. The results allowed us to characterize the children on renal conservative management, which showed a predominance female, white, from two months to 11 years-old age group; presented initial diagnosis of neonatal urinary tract malformations and glomerulopathies, on renal conservative management duration of two months to three years, family risk for chronic kidney disease; live with the nuclear family in urban areas and have siblings. They used public services for chronic renal failure treatment and most of them received Welfare Benefits. The importance for nurses assessing family history configuration and references to kidney disease using genograms as therapeutic tools is stressed, seeking to reduce the time between the diagnosis and early treatment. It should be noted that primary care nurses can reduce anxiety in families of children on renal conservative management in need of invasive procedures at school, as well as providing relevant healthcare information.
\end{abstract}

\section{KEYWORDS: Child. Nursing. Chronic renal failure. Health Profile}

\section{INTRODUCTION}

Chronic kidney disease (CKD) is a complex syndrome triggered by structural abnormalities and/or irreversible loss of kidney function for more than three months (KDIGO, 2013). It is considered a silent pathology since, in general, children do not show symptoms until a serious dysfunction manifests itself. When established, it compromises the development and modifies the child's daily routine due to restrictions it causes such as growth deficit, low self-esteem, behavioral and learning problems (WONG et al., 2014).

During childhood, the main kidney diseases affecting infants and preschoolers are related to urinary tract malformations, which can be detected during prenatal care through imaging tests (NOGUEIRA; PAZ 2016). In the schoolers and teenagers age groups, glomerulopathies, uropathies, sequelae of acquired diseases predominates and causes related to hereditary kidney diseases arise (HOCKENBERRY; WILSON, 2014)

The kidney disease stage is classified by Glomerular Filtration Rate (GFR), determined by glomerular filtration rate, considered the best form of evaluation, based on measurements of serum creatinine where stage 1: GFR >=90; stage 2 :GFR 60 to 89 ; stage 3: GFR 30 to 59; stage 4: GFR 15 to 29; stage 5: GFR < 15 (HOGG et al., 2013). Conservative treatment starts after the diagnosis of kidney disease (stage 1 to 3), with greater brevity, thereby, increasing the chances of preserving kidney function which may delay the need of substitutive renal therapy (NOGUEIRA; PAZ, 2016).

Experiencing kidney disease in childhood is considered a complex event by the family, since it involves all members and triggers changes in family dynamics (LISE et al., 2016). Also, it may provoke family overprotective behavior towards the child because, being a chronic disease, concerns about future loss are part of life-cycle planning in subtle and disguised ways (ROLLAND .1998). Moreover, the mother inability to keep employment and economic impact generated by the disease cause more family stress. However, health service support can improve the life quality of children with CKD and their families (MEDWAY et al., 2015). This study aimed to know the clinical profile and the family configuration of children with chronic renal failure on conservative management. 


\section{MATERIAL AND METHODS}

This is an exploratory, descriptive study of qualitative approach which is part of the master's thesis entitled "Experiences of family caregivers of children with chronic renal failure on renal conservative management in Southern Brazil" defended in 2015.

Family caregivers of children with chronic renal failure on renal conservative management participated, regarded as the person who spends more time involved in child care. Inclusion criteria were being the main family caregiver of the child on renal conservative management in Nephrology services in southern Rio Grande do Sul, more than 18 years-old and speaking Portuguese.

Data were obtained from April to August 2015, from patient's charts consulting through proper form to identify the initial diagnosis and conservative management duration. Semi-structured interviews were conducted with family caregivers of children with chronic renal failure on renal conservative management on nephrologic monitoring to assess the family structure and the child characteristics through personal interviews in confidential environment, chosen by participants.

Data were organized and analyzed descriptively (GIBBS, 2009) concomitant to the interviews, because it is a method commonly used to describe, analyze and report data subjects and patterns, also, such an approach shows what people and contexts have in common and explains them in terms of those characteristics.

The free Software "Dia Portable", which creates and edits vector graphics, flowcharts and diagrams, was used to construct genogram and ecomap because they allow to assess the family setting emphasizing family kidney disease occurrence specifically, since their primary function is organizing data related to the family and their relational processes (WRIGHT; LEAHEY; 2012). This representation form was chosen for being widely used as tool for clinical work of nurses because it allows quick and comprehensive view of family organization and its main features, thus constituting a relational map, which is critical to pediatric nursing when identifying strengths and weaknesses of the family.

The study development respected ethical principles of research involving human subjects, in accordance with resolution 466/2012 (BRAZIL, 2012) approved by Research Ethics Committee opinion number 985,770. To ensure anonymity, participants were identified by letter "E" followed by the Arabic number corresponding to the chronological order in which the interviews were conducted. Therefore, after the presentation of the objectives, a two-part informed consent form was provided, signed by the family caregiver and the researcher, each getting one via. Freedom of spontaneous participation in the research and right of withdrawal at any time from it without any form of prejudice were assured.

\section{RESULTS}

Family caregivers participated in this study, which allowed to characterize 11 children with chronic renal failure on renal conservative management. Predominance of female, white, in the six months-11 years-old age group; initial diagnosis of neonatal urinary tract malformations and glomerulopathies, renal conservative management duration of two months to three years were observed. Three of the children are on treatment for more than five years and most present family risk for chronic kidney disease (Table 1).

Most children live with their nuclear family and siblings in urban areas and the pre-schooled ones do not have access to formal education. Catholic religion predominated, they use public health service for CKD treatment and receive welfare benefit by Social Assistance Law (LOASLei Orgânica da Assistência Social) (Table 2).

Family caregivers genograms identified chronic kidney disease occurrence in the family of children with chronic renal failure on renal conservative management as the examples presented in Figures 1 and 2. 
Table 1. Clinical profile of children with chronic renal failure on renal conservative management by sex, ethnicity, age, treatment time, chronic kidney disease occurrence in family and primary caregiver. Pelotas, RS, Brazil, 2015.

\begin{tabular}{|c|c|c|c|c|c|c|}
\hline Sex & Color & Age & $\begin{array}{l}\text { Initial } \\
\text { diagnosis }\end{array}$ & $\begin{array}{l}\text { Conserv } \\
\text { managen } \\
\text { duration }\end{array}$ & $\begin{array}{lll}\text { tive } & \text { CKD } \\
\text { nent } & \text { family }\end{array}$ & $\begin{array}{l}\text { Primary } \\
\text { caregiver }\end{array}$ \\
\hline$(\mathrm{F})$ & White & 1 year-old & UTI + Agenesis & 1 year & No & Mom \\
\hline$(\mathrm{F})$ & White & 5 years-old & $\begin{array}{l}\text { Polycystic } \\
\text { kidneys }\end{array}$ & 5 years & Cousin/KT & Mom \\
\hline$(\mathrm{F})$ & White & 3 years-old & $\begin{array}{l}\text { Polycystic } \\
\text { kidneys }\end{array}$ & 3 years & Grandfather/KT & Mom \\
\hline M & White & $\begin{array}{l}2 \text { months- } \\
\text { old }\end{array}$ & $\begin{array}{l}\text { Polycystic } \\
\text { kidneys }\end{array}$ & 2 months & No & Mom \\
\hline$(\mathrm{F})$ & White & 9 years-old & $\begin{array}{l}\text { Neurogenic } \\
\text { bladder }\end{array}$ & 7 years & $\begin{array}{l}\text { Cousin/ } \\
\text { CKD }\end{array}$ & Mom \\
\hline$(\mathrm{F})$ & White & $\begin{array}{l}11 \text { years- } \\
\text { old }\end{array}$ & UTI & 1 year & No & Mom \\
\hline (F) & White & 2 years-old & Hydronephrosis & 2 years & $\begin{array}{l}\text { Dad/ } \\
\text { Renal asymmetry }\end{array}$ & Mom \\
\hline (F) & White & 8 years-old & UTI & 3 years & Grandmother/ CKD & Mom \\
\hline $\mathrm{M}$ & Black & $\begin{array}{l}11 \text { years- } \\
\text { old }\end{array}$ & $\begin{array}{l}\text { Neurogenic } \\
\text { bladder }\end{array}$ & 11 years & No & Mom \\
\hline (F) & White & 3 years-old & $\begin{array}{l}\text { Nephrotic } \\
\text { syndrome + SAH }\end{array}$ & 6 months & No & Mom \\
\hline (F) & White & $\begin{array}{l}7 \text { years- } \\
\text { old }\end{array}$ & $\mathrm{UTI}+\mathrm{SAH}$ & 3 years & No & Mom \\
\hline
\end{tabular}

Table 2. Socioeconomic and demographic Characterization of children with chronic renal failure on renal conservative management according to household, family structure, presence of siblings, formal education, access to health service and welfare benefits. Pelotas, RS, Brazil, 2015.

\begin{tabular}{llllll}
\hline Household & $\begin{array}{l}\text { Family } \\
\text { structure }\end{array}$ & $\begin{array}{l}\text { To } \\
\text { have } \\
\text { Sibling } \\
\text { s }\end{array}$ & $\begin{array}{l}\text { Formal } \\
\text { education }\end{array}$ & $\begin{array}{l}\text { Health } \\
\text { service }\end{array}$ & $\begin{array}{l}\text { Welfare } \\
\text { Benefit } \\
\text { (LOAS) }\end{array}$ \\
\hline Urban & Nuclear family & Yes & No & Public & No \\
Urban & Single-Parent & No & No & Public & Yes \\
Rural & Nuclear family & No & No & Public & No \\
Urban & Nuclear family & Yes & No & Private & No \\
Urban & Nuclear family & Yes & Yes & Public & Yes \\
Urban & Nuclear family & Yes & Yes & Public & No \\
Urban & Single-parent & No & No & Public & Yes \\
Urban & Nuclear family & Yes & Yes & Public & Yes \\
Urban & Nuclear family & Yes & Yes & Public & Yes \\
Rural & Nuclear family & No & No & Public & No \\
\hline
\end{tabular}



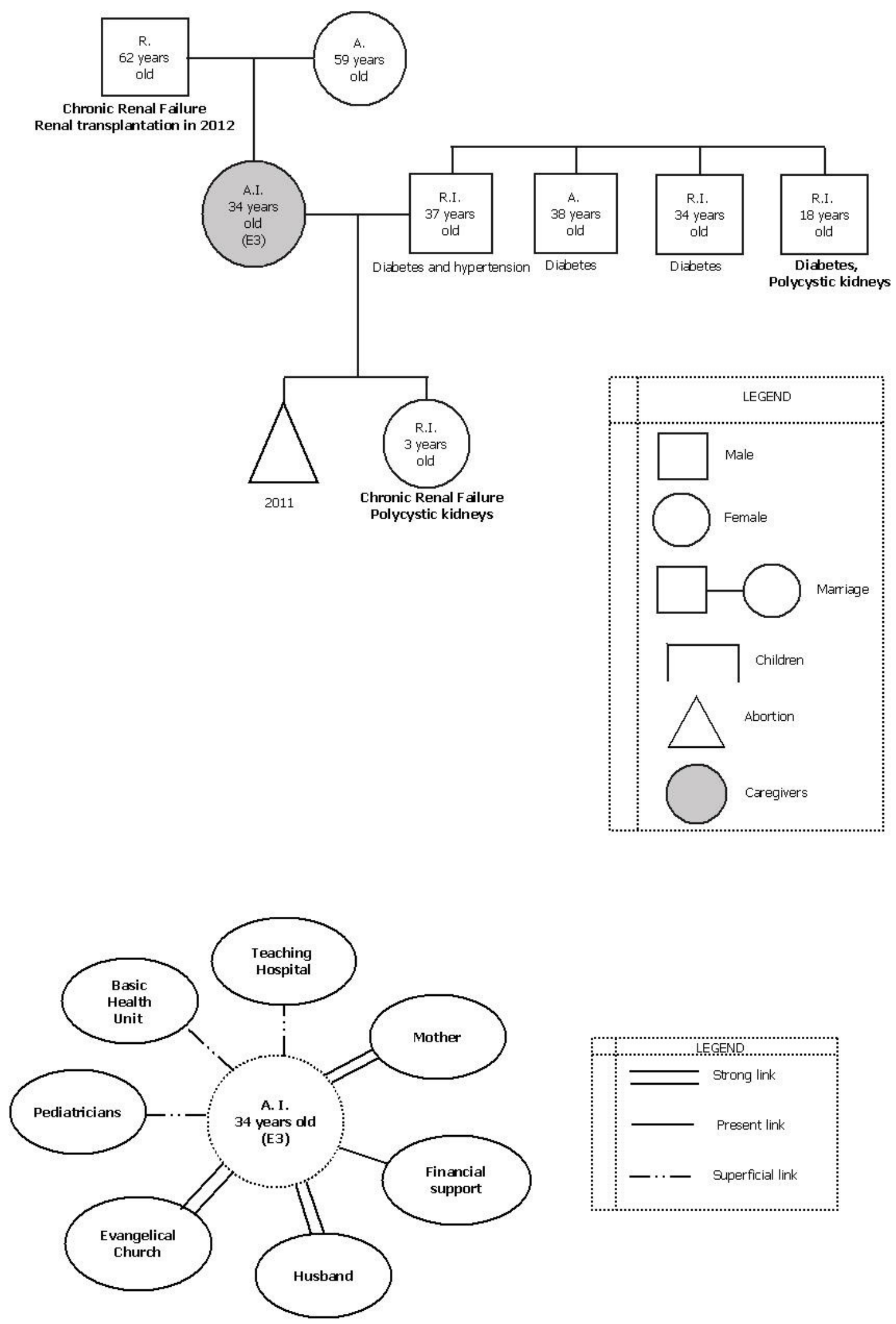

Figure 1. Family caregivers (E3) of children with chronic renal failure on renal conservative management genograms and ecomaps, Pelotas, Brazil, 2015. 

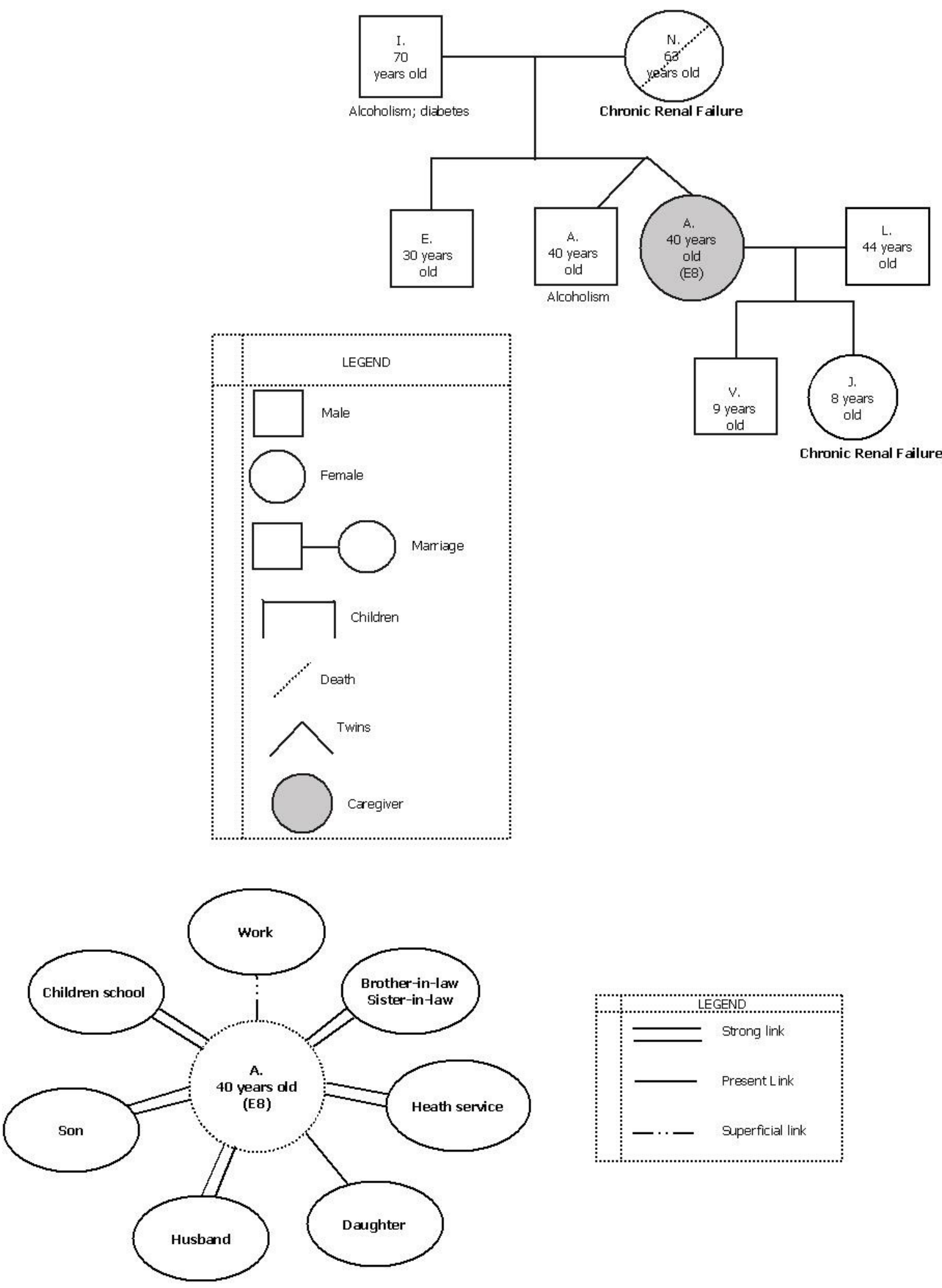

Figure 2. Family caregivers (E8) of children with chronic renal failure on renal conservative management genograms and ecomaps, Pelotas, Brazil, 2015. 


\section{DISCUSSION}

Results of this study showed that most children with chronic renal failure on renal conservative management are female, result similar to that found in a Brazilian study (MANGIA; ANDRADE, 2013). There was a predominance of white children, since the population of southern Brazil presents European features (BRAZIL, 2011) However, there are no records of CKD predominance in a particular ethnicity.

Households of children part of this study were predominantly urban. However, three lived in rural households. Household may be a critical factor to children with chronic renal failure on renal conservative management, considering difficult access can be a barrier. Literature suggests that family caregivers of children with renal disease in rural households should be provided with increased attention and support (ZHANG et al., 2015).

Main causes of kidney disease in children were urinary tract malformations (Polycystic kidneys, neurogenic bladder, hydronephrosis, renal Agenesis) related to congenital and hereditary disorders and to glomerulopathies, (INGELFINGER et al., 2014) considering that among main kidney diseases that affect infants and preschoolers, urinary tract malformations and glomerulopatias predominate (INGELFINGER et al., 2014; SANTOS et al., 2014).

After the first year of life, urinary tract infection (UTI) is predominant in female, since the urethra is short and provides a route to invasion of microorganisms which may favor the occurrence of UTI, and closing the urethra after urinating can cause bacteria return to the bladder (HOCKENBERRY; WILSON, 2014). In males, Glomerulonephritis is more frequent in 3-12 yearsold children and adolescents. That way, it is believed that children with congenital malformations experience a slower progression of kidney disease compared to those with Glomerulonephritis, (HARAMBAT et al.., 2014) indicating that those with congenital malformations evolve into CKD in adulthood more frequently. In addition, complications of other non-kidney diseases may affect the child's kidneys secondarily, causing significant morbidity and mortality beyond childhood (INGELFINGER et al., 2016).

In relation to the elapsed time of the renal failure diagnosis, results showed predominance of neonatal period resulting from congenital malformations. Consequently, it highlights the importance of conducting tests promoting the intrauterine period diagnosis, aiming to reduce morbidity and mortality by CKD in childhood. Because delayed diagnosis favors the development of comorbidities as $\mathrm{SAH}$, similar result was reported in studies with children and adolescents, which presented congenital malformation and $\mathrm{SAH}$ as causes of CKD (SANTOS; ROCHA; KOCH, 2014). (Saints; Rock; KOCH, 2014).

Conservative management time was from two months to three years, and children spent on average five years on this treatment (GERSON et al., 2010). It should be noted that the greater the length of conservative management, the less the need for the children to undergo any form of Renal Substitution Therapy (RST) as peritoneal dialysis or renal transplantation (NOGUEIRA et al., 2011).

Studies with family members of children with chronic illness showed that $10 \%$ have a family history of chronic illness (KHANNA et al., 2015). CKD in childhood presents, among its more common etiologies, kidney and urinary tract congenital malformations and hereditary disorders (KDIGO, 2013), as demonstrated when constructing the genograms of this study. Thus, the multidisciplinary team can contribute to prevent its occurrence (BITTENCOURT, 2015). And the multiprofissional team, in primary healthcare, can use genograms as therapeutic tools to meet the occurrence of family genetic diseases in all development stages. Although there is no delineation of the nurse role as a genetic counselor in the Unified Health System(SUS), this insertion may be an excellent strategy to promote prophylaxis, diagnosis and treatment, contributing to decrease morbidity and mortality rates linked to genetic diseases (CARDOSO; JUNIOR, 2016).

Nurse support is important to the family adapting to health care of the child with chronic renal failure on renal conservative management, since the maintenance of the treatment depends on the understanding of everyone involved, including siblings, in order to reduce the consequences of CKD progression. Therefore, it is suggested to use genograms as therapeutic tools favourable to the family approach by the nurse (NASCIMENTO et al., 2014). And to identify CKD family occurrence .

Most family caregivers of children on renal conservative management access healthcare service by Unified Health System (SUS), to some of them such a choice happened because that was the only specialized healthcare public service in the region. Only one caregiver reported using additional specialized monitoring service in another municipality provided by the company where he works. Access to healthcare is a basic human need, considered a social determinant of health that may 
affect the quality of life of individuals (DALCIN et al., 2016).

The simple nuclear family configuration was predominant for children in this study, followed by two single parent families and one reconstituted nuclear family. The simple nuclear family consists of a couple and their children; single-parent can be male or female and is organized around a person who has no partner residing in the same household, which may reside with their children or not ; reconstituted nuclear, a couple whose one or both spouses have already had other previous union, having children or not (SOUZA; PERES, 2002). Brazilian families profile, according to IBGE, shows that the common family arrangement continues to be a couple with children in $55 \%$ of households. From a total of $27,400,000$ couples with children, a sixth part (16.3\%) lives with stepchildren, besides their children, or only with a stepchild (BRAZIL, 2010).

Children mostly have siblings, since all families live the moment of the family life cycle configuration classified as "Families with young children" and 4 families, in addition to this classification, are in the "Families with teenagers" vital cycle. Study pointed out that most families of children in chronic conditions have on average two children aged six years-old (KHANNA et al., 2015). Depending on family configuration and support, the care offered to the child with chronic renal failure on conservative treatment can be compromised, since the person carrying a hereditary or childhood disorder brings the evolutionary experience of loss to their adult relationships (ROLLAND, 1998).

Pre-school Children with chronic renal failure on renal conservative management, in this study, were not attending school, which is in violation of the Statute of the child and adolescent in article 54 "it is State duty to ensure child care in daycare and preschool to zero to six years-old children ", (BRAZIL, 2008) and changes in law13,303/2016 determined the maximum age to attend early childhood education as five years old (BRAZIL, 2016). This form of deletion may harm the child's socialization, since school is the first social circle (TJADEN et al., 2012).

Some schooler children with kidney disease, as in this study, may require vesical probe for relief at school. This requirement may cause insecurity to the children families. In this regard, the importance of the nurse and school interaction to promote health in childhood is stressed, performing health care and education as healthy eating habits stimulating activities (LEITE et al., 2014; SOUZA; SALVIANO; MARTINS, 2015).

Most caregivers received State Assistance Benefit, however, studies conducted with family caregivers of children in chronic conditions showed that a minority of caregivers receive Welfare Benefit/Social Assistance from the State (KHANNA et al., 2015). This fact reveals the importance of women acknowledgment of their financial rights, considering that financial assistance is needed to perform full-time care because there is no time to engage in remunerated activities (MEDWAY et al., 2015).

This investigation enabled to meet the characteristics of children with chronic renal failure on conservative treatment and their family configuration and to recognize the importance of family history of chronic kidney disease occurrence since prenatal period, by the presence of urinary tract malformations, seeking to reduce the time between the diagnosis and first treatment, preventing damages to the child health.

In these terms, primary health care nursing can use genogram as therapeutic tool to assess family genetic diseases occurrence, aiming the earliest possible children's access to specialized monitoring, chiefly children residing in rural areas, which may present, more frequently, diagnosis delay .

It is important to emphasize the importance of health education in primary health care to improve support to families, in this way the involvement of nurses with the school could improve family safety about the performance of invasive procedures and health education promotion. And in primary care, to promote familycentric care, aiming adaptation and maintenance of the child on renal conservative management.

\section{ACKNOWLEDGEMENTS}

To the Coordenação de Aperfeiçoamento de Pessoal de Nível Superior (CAPES) for $\mathrm{PhD}$ Scholarship of the first author. To the National Council for Scientific and Technological Development $(\mathrm{CNPq})$ for research productivity scholarship of the second author and scientific initiation scholarship of the last author. This survey was conducted without specific project financing. 
RESUMO: Estudo realizado com o objetivo de conhecer o perfil clínico e a configuração familiar das crianças em tratamento conservador renal. Estudo descritivo de abordagem qualitativa, desenvolvido a partir de entrevistas semiestruturadas e a construção do genograma e ecomapa de cuidadores familiares de crianças em tratamento conservador renal. A coleta de dados ocorreu no período de abril a agosto de 2015 e utilizou-se a análise descritiva. Os resultados permitiram caracterizar as crianças em tratamento conservador renal, as quais apresentaram predomínio do sexo feminino, cor branca, faixa etária entre dois meses a 11 anos, com diagnóstico inicial de malformações do trato urinário e glomerulopatias, o qual ocorreu no período neonatal, o tempo de tratamento conservador renal foi de dois meses a três anos, apresentam histórico de doença renal crônica na família, residem com a família nuclear em área urbana e tinham irmãos. Para o tratamento da doença renal crônica utilizavam serviço público e a maioria recebia Benefício Assistencial. Salienta-se a importância do enfermeiro conhecer o histórico familiar na sua configuração e referências à doença renal utilizando o genograma como instrumento terapêutico, buscando reduzir o tempo entre o diagnóstico e inicio do tratamento. Ressalta-se que o enfermeiro na atenção primária pode reduzir a ansiedade das famílias das crianças com necessidades de procedimentos invasivos na escola, bem como com informações de saúde pertinentes ao cuidado.

PALAVRAS-CHAVE: Criança. Enfermagem. Insuficiência Renal. Perfil de Saúde

\section{REFERENCES}

BITTENCOURT, Z. Z. L. C. Epidemiologia da doença renal policística em pacientes renais crônicos no município de Campinas. Serviço social \& saúde v. 1, n. 1, p. 121-152, 2015. http://periodicos.sbu.unicamp.br/ojs/index.php/sss/article/view/8634836/2754

BRASIL. Conselho Nacional de Saúde. Diretrizes e normas regulamentadoras de pesquisas envolvendo seres humanos - Resolução 466. Brasília: Ministério da Saúde, 2012. Disponível em: http://conselho.saude.gov.br/resolucoes/2012/Reso466.pdf Acesso em: 13 mai. 2016

BRASIL. Ministério do Planejamento, orçamento e Gestão. Instituto Brasileiro de Geografia e Estatística (IBGE). Características Étnico-Raciais da População: um estudo das categorias de classificação de cor ou raça, 2008. Rio de Janeiro. 2011. Disponível em: http://biblioteca.ibge.gov.br/visualizacao/livros/liv49891.pdf.

BRASIL. Instituto Brasileiro de Geografia e Estatística (IBGE). Estatísticas do registro civil. Rio de Janeiro, 2010.

BRASIL. Lei no 13.306, de 4 de julho de 2016. Altera a Lei no 8.069, de 13 de julho de 1990 - Estatuto da Criança e do Adolescente. Câmara dos Deputados. Brasília, 2016. Disponível em: http://www2.camara.leg.br/legin/fed/lei/2016/lei-13306-4-julho-2016-783308-publicacaooriginal-150706pl.html Acesso em: 13 mai. 2016.

BRASIL. Ministério da Saúde. Estatuto da Criança e do Adolescente. Brasília: Ministério da Saúde; 2008. Disponível em:http://bvsms.saude.gov.br/bvs/publicacoes/lei_8069_06_0117_M.pdf Acesso em: 13 mai. 2016.

CARDOSO, M. C. V.; JUNIOR, D. A. C. Enfermagem em genômica: o aconselhamento genético nas práticas assistenciais. Revista Mineira de Enfermagem, v. 20, n. 1, 2016. Disponível em: http://www.reme.org.br/artigo/detalhes/1090. Acesso em: 20 dez. 2016.

DALCIN, C. B.; BACKES, D. S.; INEUDOTTO, J.; SOUZA, M. H. T.; MORESCHI, C.; BÜSCHER, A. Determinantes sociais de saúde que influenciam o processo de viver saudável numa comunidade vulnerável. Journal of Nursing UFPE on line, v. 10, n. 6, p. 1963-70, 2016. Disponível em: http://www.revista.ufpe.br/revistaenfermagem/index.php/revista/article/viewArticle/7044. Acesso em: $10 \mathrm{dez}$. 2016.

GERSON, A.C.; WENTZ, A.; ABRAHAM, A.G.; MENDLEY, S.R.; HOOPER, S.R.; BUTLER, R.W.; WARADY, B. A. Health-related quality of life of children with mild to moderate chronic kidney disease. Pediatrics, v.125, n.2, p.349-357, 2010. Disponível em; http://pediatrics.aappublications.org.scihub.cc/content/125/2/e349. Acesso em: 13 mai. 2016. 
GIBBS, Graham. Análise de dados qualitativos: coleção pesquisa qualitativa. Bookman Editora, 2009.

HARAMBAT, J.; VAN STRALEN, K. J.; KIM, J. J.; TIZARD, E. J. Epidemiology of chronic kidney disease in children. Pediatric Nephrology, v. 27, n. 3, p. 363-373, 2012. Disponível em:

http://download.springer.com/static/pdf/134/art\%253A10.1007\%252Fs00467-011-1939-1.pdf. Acesso em: 13 mai. 2016.

HOCKENBERRY, M. J.; WILSON, D. Wong's nursing care of infants and children. Elsevier Health Sciences, 2014.

HOGG, R.J.; FURTH, S.; LEMLEY, K.; PORTMAN, R.; SCHWARTZ, G. J.; CORESH, J.; EKNOYAN, G. National Kidney Foundation's Kidney Disease Outcomes Quality Initiative clinical practice guidelines for chronic kidney disease in children and adolescents: evaluation, classification, and stratification. Pediatrics, v. 111, n.6, p. 416-1421, 2013. Disponível em: http://pediatrics.aappublications.org/content/111/6/1416.fulltext.pd Acesso em: 16 jun. 2016.

INGELFINGER, J. R.; KALANTAR-ZADEH, K.; SCHAEFE F. Averting the legacy of kidney disease - focus on childhood. Kidney International, v. 89, n. 3, p. 512-18, 2016. Disponível em:

http://openventio.org/Volume1_Issue3/Averting_the_Legacy_of_Kidney_Disease_Focus_on_Childhood_NPOJ _1_e004.pdf. Acesso em: 13 mai. 2016.

KDIGO (Clinical practice guideline for the evaluation and management of chronic kidney disease) Kidney International, v. 3, n.(Suppl), p. 1-150, 2013. Disponível em: Acesso em: 3 mai. 2016.

KHANNA, A. K.; PRABHAKARAN, A.; PATEL, P.; GANJIWALE, J. D.; NIMBALKAR, S. M. Social, Psychological and Financial Burden on Caregivers of Children with Chronic Illness: A Cross-sectional Study.

Indian Journal of Pediatrics, v. 1, n. 6, p. 1006-11, 2015. Disponível em: http://link.springer.com.scihub.cc/article/10.1007/s12098-015-1762-y Acesso em: 13 mai. 2016.

LEITE, C. T.; VIEIRA, R. P.; MACHADO, C. A.; QUIRINO, G. S.; MACHADO, M. F. A. S. Prática de educação em saúde percebida por escolares. Cogitare Enfermagem, v. 19, n. 1, p. 13-19, 2014. Disponível em: http://revistas.ufpr.br/cogitare/article/view/35925. Acesso em: 13 mai. 2016.

LISE, F.; SCHWARTZ, E.; DOS SANTOS, B. P.; ECHEVARRÍA-GUANILO, M. E.; MILBRATH, V. M.; GARCIA, R.P. Caring the families of children with renal failure: integrative review. Journal of Nursing UFPE on line, v. 10, n. 3, p. 1535-1543, 2016. Disponível em:

http://www.revista.ufpe.br/revistaenfermagem/index.php/revista/article/viewArticle/7710 Acesso em: 12 mai. 2016.

MANGIA, C. M. F.; ANDRADE, M. C. Epidemiological Aspects of kidney Failure in Hospitalized Children in Brazil. Journal of Nephrology, v. 6, n. 2, 2013. Disponível em: http://www.omicsonline.org/openaccess/epidemiological-aspects-of-kidney-failure-in-hospitalized-children-inbrazil-2161-0959-1000245.pdf Acesso em: 12 mai. 2016.

MEDWAY, M.; TONG, A.; CRAIG, J. C.; KIM, S.; MACKIE, F.; MCTAGGART, S.; WONG, G. Parental perspectives on the financial impact of caring for a child with CKD. American Journal of Kidney Diseases, $v$. 65, n. 3, p. 384-93, 2015. Disponível em: http://www.ajkd.org/article/S0272-6386(14)01152-4/pdf Acesso em: 13 mai. 2016.

NASCIMENTO, L. C.; DANTAS, I. R. O.; ANDRADE, R. D.; MELLO, D. F. Genograma e ecomapa: contribuições da enfermagem brasileira. Texto Contexto Enfermagem, v. 23, n. 1, p. 211-20, 2014. Disponível em: http://www.scielo.br/pdf/tce/v23n1/pt_0104-0707-tce-23-01-00211.pdf. Acesso em: 13 mai. 2016 
NOGUEIRA, P. C. K.; DE SANTIS, L,F.; CAMARGO, M. F.; LEÃO, E. R.; BENNINGHOVEN, J. R.; GONÇALVES, N. Z.; SESSO, R. C. Prevalência estimada da doença renal crônica terminal em crianças no Estado de São Paulo. Revista da Associação Médica Brasileira, v. 57, n. 4, p. 443-49, 2011. Disponível em: http://ac.els-cdn.com/S0104423011703682/1-s2.0-S0104423011703682-main.pdf. Acesso em: 13 mai. 2016.

NOGUEIRA, P. C. K.; PAZ, I. P. Signs and symptoms of developmental abnormalities of the genitourinary tract. Journal of Pediatrics, v. 92, n. 3, p. 57-63, 2016. Disponível em: https://www.sciencedirect.com/science/article/pii/S2255553616300039. Acesso em: 13 mai. 2016.

ROLLAND J. Ajudando famílias com perdas antecipadas. In: WALSH F; MCGOLDRICK M. Morte na família: sobrevivendo as perdas. Porto Alegre: Artmed, 1998.

SANTOS, R. P.; ROCHA, D. L. B.; KOCH, V. H. K. Componentes clínico-epidemiológicos de crianças e adolescentes em hemodiálise. Cogitare Enfermagem, v. 9, n. 2, p. 337-343, 2014. Disponível em: http://www.revistarene.ufc.br/vol12n4_pdf/a13v12n4.pdf Acesso em: 13 mai.2016.

SOUZA, L. B. M.; SALVIANO, C. F.; MARTINS, G. Contexto escolar e sintomas de trato urinário inferior: revisão integrativa da literatura. Cogitare Enfermagem, n. 20, n. 1, p. 198-206, 2015. Disponível em: http://revistas.ufpr.br/cogitare/article/view/37477 Acesso em: 13 mai. 2016.

SOUZA, S. M. G.; PERES, V. L. A. Famílias de camadas populares: um lugar legítimo para a educação/formação dos filhos. O Social em Questão, v. 7, n. 1 p. 63-74, 2002.

TJADEN, L.; TONG, A.; HENNING, P.; GROOTHOFF, J.; CRAIG, J. C. Children's experiences of dialysis: a systematic review of qualitative studies. Archives of Disease in Childhood, v. 97, n. 5, p. 395-402, 2012. Disponível em: http://www.kidneyresearch.org/publications/journal_publications/CKR_pubs_2012.pdf. Acesso em: 13 mai. 2016.

WONG, G.; MEDWAY, M.; DIDSBURY, M.; TONG, A.; TURNER, R.; MACKIE, F.; CRAIG, J. C. Health and wealth in children and adolescents with chronic kidney disease (K-CAD study). BMC public health, v. 14, $\mathrm{n}$. 307, p. 1-5, 2014. Disponível em: https://www.ncbi.nlm.nih.gov/pmc/articles/PMC4233636/pdf/1471-2458-14307.pdf. Acesso em: 16 jun. 2016.

WRIGHT, L.; LEAHEY, M. Enfermeiras e famílias: um guia para avaliação e intervenção na família. São Paulo: Roca, 2012.

ZHANG, Y.; WEI, M.; SHEN, N.; ZHANG, Y. Identifying factors related to Family management during the coping process of families with child Hood chronic conditions: A multi-sitestudy. Journal of Pediatric Nursing, v. 30, n. 1, p. 160-73, 2015. Disponível em: http://www.sciencedirect.com.scihub.cc/science/article/pii/S0882596314002693. Acesso em: 13 mai. 2016. 